\title{
Morphometric analysis of debris flow basin of Harsovska river (Southwest Rila, Bulgaria)
}

\section{Морфометричен анализ на селеви потоци в басейна на река Хърсовска (Югозападна Рила, България)}

\author{
Vanya Stoycheva ${ }^{1}$, Dimitar Krenchev ${ }^{2}$ \\ Ваня Стойчева ${ }^{1}$, Димитър Кренчев ${ }^{2}$ \\ ${ }^{1}$ National Institute of Geophysics, Geodesy and Geography, Bulgarian Academy of Sciences, 1113 Sofia; \\ E-mail: vanya.e.stoycheva@gmail.com \\ ${ }^{2}$ Sofia University “St. Kliment Ohridski”, Faculty of Geology and Geography, Department of Climatology, Hydrology \\ and Geomorphology, 1504 Sofia; E-mail: dkrenchev@gea.uni-sofia.bg
}

\begin{abstract}
The analysis of morphometric properties of a river basin and identification of the correlation between the specific topography and the processes of debris flow is crucial for identifying the areas with a high ecological risk. Results of the fieldwork and analysis in the GIS environment show the high risk of debris flow for the Harsovska river basin.
\end{abstract}

Keywords: Southwest Rila, debris flow, morphometric analysis, catchments.

\section{Introduction}

Harsovska river as part of the Struma river basin has been characterized by repeated debris flow occurrences. The latest most impactful event was a flood on the July 2, 1954 with a 5-6 m flood wave that caused the death of 13 people. Both left and right tributaries of Struma river generate debris flows, which frequently cause deaths and damages to the infrastructure (Kenderova, Vasilev, 1997; Kenderova et al., 2013; Baltakova et al., 2018; Nikolova et al., 2018). Anti-erosion activities for mitigation of the ecological risk are accomplished by strengthening the slopes through afforestation (Pinus nigra, Populus sp., Betula sp.) and construction of rockretaining facilities (barrages and counter-barrages) in the 60 s and 70 s of 20 th century and continued in nowadays.

The main purpose of this study is to analyze selected morphometric properties of the Harsovska river basin and to identify the relationship between the specific topography and the processes of debris flow. The following morphometric parameters were considered in this study, to assess the processes in the river basin: area and shape of the basin, slopes, local elevation range (LER), drainage network length, drainage density, stream frequency, etc.

\section{Study area and methods}

The study area is the Harsovska river subbasin (Fig. 1), situated in the Blagoevgradska Bistritsa river basin (Southwest Rila, Bulgaria). The basin has NW-SE direction, which follows the main slope orientation of this part of the Rila Mountain. The Harsovska river basin has an area of $31.44 \mathrm{~km}^{2}$ and an elongate, asymmetrical shape with more developed upper part. The source of the river starts from the location of about $1375 \mathrm{~m}$ asl and flows into the Blagoevgradska Bistritsa at about $461 \mathrm{~m}$.

For the analysis of morphometric parameters of the river basin, 30 meters STRM digital elevation model (DEM) [USGS, NASA] were used and transformed into $10 \mathrm{~m}$ in ArcGIS environment. Topographic maps at a scale 1:50 000 were used for digitalizing the drainage network. Further calculations were executed in GIS environment. 


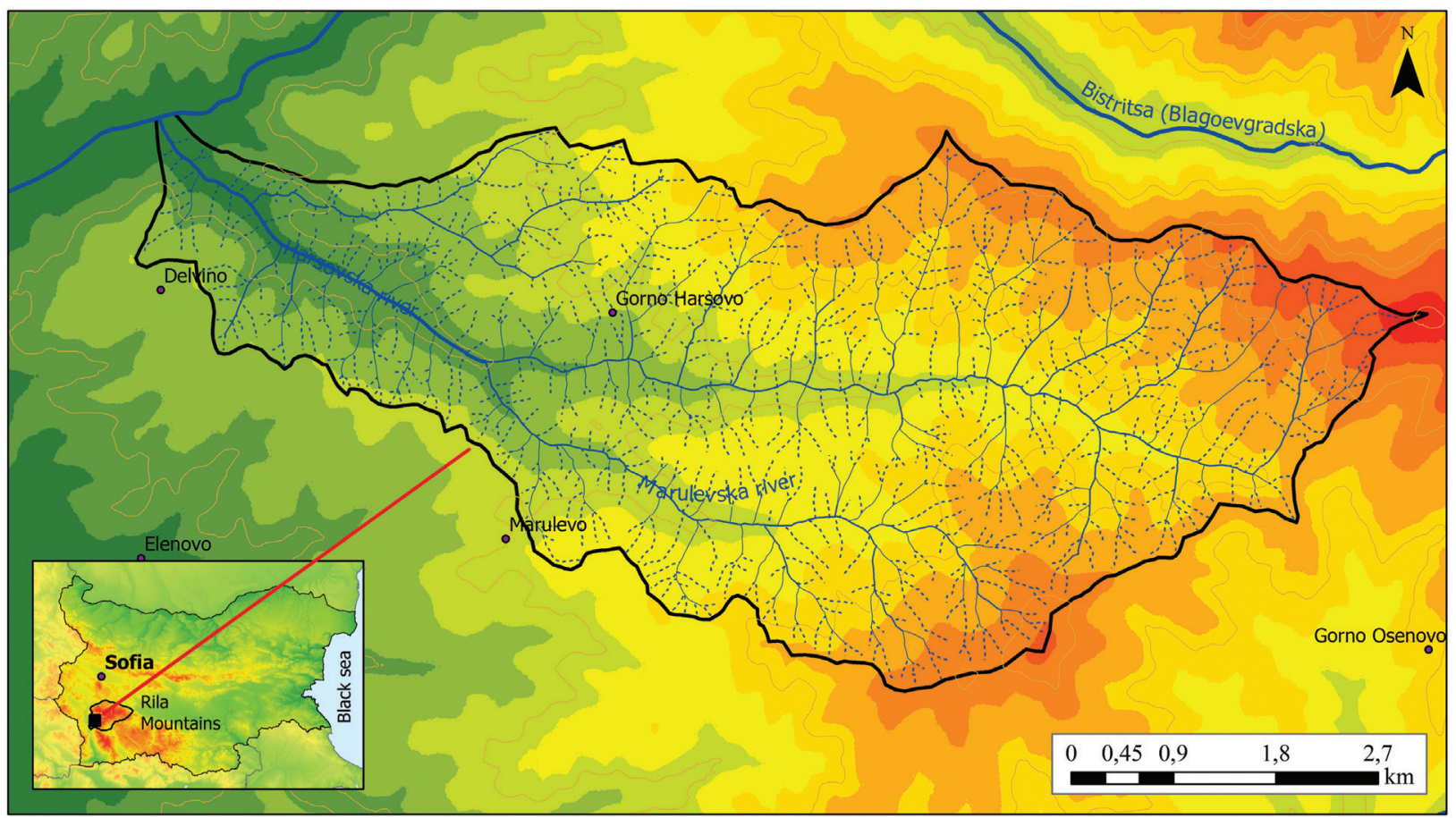

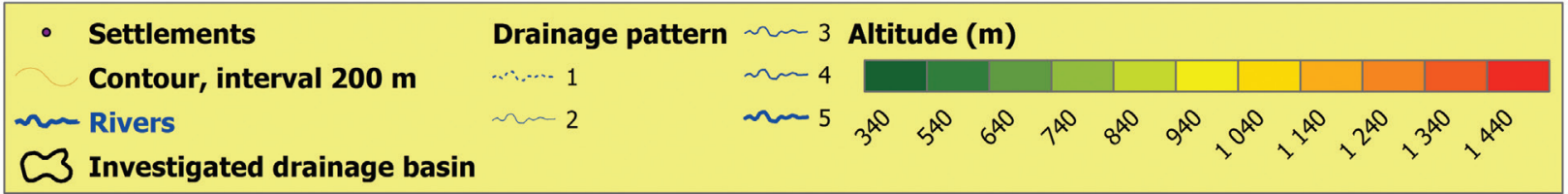

Fig. 1. Map of the study area

\section{Results and discussion}

Harsovska river basin is one of the main tributaries of Blagoevgradska Bistritsa. The largest part of the river basin area (79.6\%) is developed in height between $700 \mathrm{~m}$ and $1200 \mathrm{~m}$, as the average elevation is $902 \mathrm{~m}$, whereas the lowest parts of the basin, up to $500 \mathrm{~m}$ are only $17.5 \%$ of the territory (Table 1). The mean slope inclination of the basin is $14.83^{\circ}$, whereas more than $76 \%$ of the basin has an inclination between $8^{\circ}$ and $30^{\circ}$. The area of inflow of the major left tributary - Marulevska river (SSW of Gorno Harsovo village) in Harsovska river is characterized with the highest inclination rates in the river basin $\left(30-55^{\circ}\right)$. The drainage network of the river basin is highly developed, much more than the average, and its average density is $7.49 \mathrm{k} / \mathrm{km}^{2}$.

The average local elevation range is relatively high $-223.4 \mathrm{~m} / \mathrm{km}^{2}$. It is highest in the NE part of the basin, between the Kolov Chukar, Kyorova Chuka, and Beli Vrah peaks where it reaches $407 \mathrm{~m} / \mathrm{km}^{2}$. The central (between the villages of Parzhovo and Shopovtsi) and northern (due to the flat hill on which Tachovtsi, Stoychovtsi, and Mratvano villages are located) parts of the Harsovska river basin have the smallest LER. The LER in these areas is between 120 and $220 \mathrm{~m} / \mathrm{km}^{2}$.

Generally, with a higher LER are the right tributaries $\left(260-400 \mathrm{~m} / \mathrm{km}^{2}\right)$, whereas the left ones are characterized with lower values (190-230 m/ $\left.\mathrm{km}^{2}\right)$.

The prevailing drainage pattern in the study area is dendritic and in the separate sections of the basin - the parallel type. The connection between the two types is with a mosaic-like relief. This type of river network is formed as a result of parallel flowing rivers on equal resistance-built rock slopes. A tributary with this type of drainage pattern starts from $1150 \mathrm{~m}$, south of the nameless peak (1175.5 m), located between Kolov Chukar and Kyorova Chuka peaks in the right part of the catchment.

Acknowledgments: The study is supported by the project "Environmental protection and reducing the risk of adverse events and natural disasters", contract N 3320, 26.03.2019.

\section{References}

Baltakova, A., V. Nikolova, R. Kenderova, N. Hristova. 2018. Analysis of debris flows by application of GIS and remote sensing: case study of western foothills of Pirin Mountains. - In: Proc. 5th Intern. Confer. "Debris Flows: Disaster, 
Table 1. Morphometric parameters of the Harsovska river basin

\begin{tabular}{|c|c|}
\hline Morphometric properties & Harsovska river \\
\hline Catchment area $\left(\mathrm{km}^{2}\right)$ & 31.44 \\
\hline Source of the river ( $\mathrm{m}$ asl) & 1375 \\
\hline River outflow (m asl) & 461 \\
\hline Mean altitude of the basin (m) & 902 \\
\hline Mean local elevation range of the basin $\left(\mathrm{m} / \mathrm{km}^{2}\right)$ & 223.4 \\
\hline Mean slope inclination of the basin & $14.83^{\circ}$ \\
\hline Length of the basin $(\mathrm{km})$ & 11.0 \\
\hline Maximum width of the basin $(\mathrm{km})$ & 4.8 \\
\hline Length of the river long profile $(\mathrm{km})$ & 12.89 \\
\hline Types of drainage pattern & dendritic, parallel \\
\hline Drainage network length (km) & 235.75 \\
\hline $1^{\text {st }}$ order $(\mathrm{km})$ & 153.53 \\
\hline $2^{\text {nd }}$ order $(\mathrm{km})$ & 44.48 \\
\hline $3^{\text {rd }}$ order $(\mathrm{km})$ & 21.12 \\
\hline $4^{\text {th }}$ order $(\mathrm{km})$ & 13.07 \\
\hline $5^{\text {th }}$ order $(\mathrm{km})$ & 3.55 \\
\hline Total count of the tributaries & 857 \\
\hline Count of $1^{\text {st }}$ order tributaries & 700 \\
\hline Count of $2^{\text {nd }}$ order tributaries & 129 \\
\hline Count of $3^{\text {rd }}$ order tributaries & 23 \\
\hline Count of $4^{\text {th }}$ order tributaries & 4 \\
\hline Count of $5^{\text {th }}$ order tributaries & 1 \\
\hline Mean length of the $1^{\text {st }}$ order tributaries $(\mathrm{km})$ & 0.22 \\
\hline Mean length of the $2^{\text {nd }}$ order tributaries $(\mathrm{km})$ & 0.34 \\
\hline Mean length of the $3^{\text {rd }}$ order tributaries $(\mathrm{km})$ & 0.92 \\
\hline Mean length of the $4^{\text {th }}$ order tributaries $(\mathrm{km})$ & 3.27 \\
\hline Mean length of the $5^{\text {th }}$ order tributaries $(\mathrm{km})$ & 3.55 \\
\hline Drainage density $\left(\mathrm{km} / \mathrm{km}^{2}\right)$ & 7.49 \\
\hline Stream frequency $\left(\right.$ count $\left./ \mathrm{km}^{2}\right)$ & 27.25 \\
\hline
\end{tabular}

Risk, Forecast, Protection”. Tbilisi, Georgia, Publishing House "Universial", 22-31.

Dzherev, R. 2019. The flood in Blagoevgrad on July 2, 1954. https://www.monitor.bg/bg/a/view/potopyt-v-blagoevgradot-2-uli-1954-godina-169499 (in Bulgarian).

Kenderova, R., A. Baltakova, G. Ratchev. 2013. Debris flows in the Middle Struma Valley, Southwest Bulgaria. - In: Lóczy, D. (Ed.). Geomorphological Impact of Extreme Weather: Case Studies from Central and Eastern Europe. Springer Geography, 283-287.
Kenderova, R., I. Vasilev. 1997. Characteristic of the mudflow on the September 20, 1994 in the Zheleznitsa gorge of the Struma River. - Ann. Sofia Univ., 88, 2-Geogr., 29-50 (in Bulgarian).

Nikolova, N., G. Rachev, R. Kenderova. 2018. Possible impact of climate and weather condition on debris flows occurrence (on the example of Kresna gorge, Bulgaria). - In: Proc. 5th Intern. Confer. "Debris Flows: Disaster, Risk, Forecast, Protection”. Tbilisi, Georgia, Publishing House "Universial", 166-175. 